\title{
Plant Regeneration from Seedling Derived Explants through Callus of Eggplant (Solanum melongena L)
}

\author{
B. P. Ray*, L. Hassan and S. K. Sarker \\ Biotechnology Laboratory, Department of Biotechnology, Bangladesh Agricultural University \\ Mymensingh-2202, Bangladesh
}

*Corresponding author and Email: bpray2010@gmail.com

Received: 22 August $2010 \quad$ Accepted: 17 March 2011

\begin{abstract}
Different concentrations and combinations of hormones were used in MS medium to observe callus induction and then plant regeneration using stem, leaf and root explants. The rate of callus formation varied in different treatments used. The highest amount of callus (48.66\%) was produced on MS medium containing $2.0 \mathrm{mg} / \mathrm{l} \mathrm{BAP}$ and $0.5 \mathrm{mg} / 1 \mathrm{NAA}$ from stem after 8.2 days. The highest fresh weight of callus was $1.12,0.5$ and $0.48 \mathrm{~g}$ from stem, leaf and root, respectively. The highest percentage of regeneration (23.28\%) was recorded in MS media containing $2.0 \mathrm{mg} / \mathrm{l} \mathrm{BAP}+0.5 \mathrm{mg} / \mathrm{l} \mathrm{NAA}$ from stem after 38.8 days. However, $11.94 \%$ leaf the regeneration was obtained by $2.0 \mathrm{mg} / \mathrm{l} \mathrm{BAP}+0.5 \mathrm{mg} / \mathrm{l}$ NAA after 46.2 days. It was also found that $2.0 \mathrm{mg} / \mathrm{l} \mathrm{BAP}+0.5 \mathrm{mg} / \mathrm{l} \mathrm{NAA}$ was the best stem regeneration. The protocol in the study might be useful for the production of disease free and healthy plant materials and also it would be useful for genetic transformation of eggplant using biotechnological approach.
\end{abstract}

Keywords: 6-Benzyl amino purine (BAP), $\alpha$-Naphthalene acetic acid (NAA), Solanum melongena , regeneration.

\section{Introduction}

Eggplant (Solanum melongena L.) cultivation is usually suffered from some bacterial and virus diseases and by insects. The fruit fly (Leucinodes orbonalis), which damages up to $30 \%$ of total yield (Shukla and Upadhyay, 2000). The seedborne pathogens of previous year can be perpetuated over the generations with symptoms being expressed. Plant tissue culture offers an efficient method for pathogen free materials and germplasm preservation. Tissue culture techniques are widely used for the improvement of various crops. In vitro shoot induction from callus culture can induce genetic and epigenic changes in the regenerated plants. These genetic changes have been coined "Somaclonal variation" (Larkin et al., 1981). Calli induction and subsequent plant regeneration through calli culture generate somaclonal variation. Therefore, reproducible protocol should be established on callus induction and its subsequent plant regeneration for using the technique of somaclonal variation of the studied genotype in eggplant. Selection could be performed based on phenotypic expression of a field experiment would be fluctuated with the environmental change. However, selection based on molecular and biochemical markers are very powerful tool in plant breeding (Ofori, 2008). The potential value of tissue culture in plant breeding has been widely recognized, and it is generally used as a tool for crop improvement. Somaclonal variations were observed by Hitomi et al. (1998) among plants through somatic embryogenesis 
induced by NAA or 2, 4-D in eggplant. A high frequency of somaclonal variation was observed among plants from both methods. Embryogenesis with NAA was more efficient than 2, 4-D.

Anwar et al. (2002) cultured the aubergine leaf explants on MS media containing IAA, BA (benzyladenine), IBA, NAA or 2, 4-D at 2 $\mathrm{mg} / \mathrm{litre}$ and found that NAA produced greenish and fast-growing callus. However, 2, 4-D induced early callus from the petiole, while BA induced green callus from the upper surface of the lamina. The addition of NAA or IBA at 0.5 $\mathrm{mg} / \mathrm{l}$ in BA-supplemented medium increased the mass production of callus and shoot regeneration. The regeneration efficiency of the plant decreased in MS medium supplied with kinetin at $2 \mathrm{mg} / \mathrm{l}+\mathrm{NAA}$ at $0.5 \mathrm{mg} / \mathrm{l}$. Callus induction and plant regeneration ability have been studied in nigrum from various explants namely shoot tip, stem, leaf and root segments( Jahan and Hadiuzzaman 1996). Best callus induction was observed when the leaf segments are cultured on MS medium supplemented with $0.5 \mathrm{mg} / \mathrm{l} \mathrm{NAA}$ and $2.0 \mathrm{mg} / \mathrm{l} \mathrm{BAP}$. Mohamed (2003) grew the shoot buds of landrace pepper in Murashige and Skoog's medium with or without benzyladenine (BA) alone or in combination with IAA. The highest number of shoots was produced in the medium containing $3 \mu \mathrm{M}$ BA singly or in combination with $0.9 \mu \mathrm{M}$ IAA, and in the medium with $5 \mu \mathrm{M}$ BA singly or in combination with $1.5 \mu \mathrm{M}$ IAA. In the present study, efforts have been made to establish a protocol for efficient plant regeneration from callus culture in eggplant, using different explants. The main purpose of the present experiment was to select somaclonal variants of eggplant genotypes tolerance to brinjal shoot and fruit borer insect based on biochemical markers.

\section{Materials and Methods}

Healthy seeds of eggplant cv. Jhumki were collected from Bangladesh Agricultural Research
Institute (BARI). The seeds were then washed thoroughly in running tap water. The surface sterilization of these seeds was carried out under a Laminar Air Flow Cabinet. The floated seeds were discarded and others were rinsed in $70 \%$ ethyl alcohol for one minute, and then thoroughly washed with sterilized distilled water. The alcohol treated seeds were immersed into $0.1 \% \mathrm{HgCl}_{2}$ solution for $8-10$ minutes, few drops Tween-20 per $100 \mathrm{ml}$ was also added at that time. The seeds were then washed 5-6 times with sterilized distilled water. Sterilized seeds were placed into seed germination medium in Petri dishes. Six seeds were placed in each Petri dish and then incubated in dark till the germination of seeds in Fig. 1. These were then transferred to 16 hours light for normal seedling growth.

\subsection{Preparation of culture media}

For the induction of callus and plantlets regeneration in eggplant a number of culture media have been advocated by scientists. Cardenas et al., 1997 reported MS ( Murashige \& Skoog, 1962) medium containing 2, 4-D at various concentrations promoted callus formation in stem and leaf explants of Capsicum annuum. Growth was better with 1.5 than 1.0 $\mathrm{mg} / \mathrm{l} 2$, 4-D. The experiment was conducted in a randomized complete block design with 16 treatments replicated. The details of the treatment combinations of this experiment were presented in Table 1.

\subsection{Preparation of samples}

Stem $(2-3 \mathrm{~mm})$, leaf and root $(0.5 \mathrm{~mm})$ segments from each germinated seedling were cut using sterilized scalpel under aseptic condition. Six pieces of each segment were arranged horizontally on each petridish and gently pressed into the surface of the sterilized culture medium with various concentrations and combinations of hormones. The Petridishes were covered and sealed with Para film. 
Table 1. Treatment combination

\begin{tabular}{|c|c|c|c|}
\hline \multirow{2}{*}{ Serial No. } & Treatment combination & \multirow{2}{*}{ Serial No. } & \multirow{2}{*}{$\begin{array}{l}\text { Treatment combination } \\
\text { BAP mg/l + NAA mg/l }\end{array}$} \\
\hline & BAP mg/l + NAA mg/l & & \\
\hline Treatment 1 & $0+0$ & Treatment 9 & $3.0+0$ \\
\hline Treatment 2 & $0+0.1$ & Treatment 10 & $3.0+0.1$ \\
\hline Treatment 3 & $0+0.5$ & Treatment 11 & $3.0+0 . .5$ \\
\hline Treatment 4 & $0+1.0$ & Treatment 12 & $3.0+1.0$ \\
\hline Treatment 5 & $2.0+0$ & Treatment 13 & $4.0+0$ \\
\hline Treatment 6 & $2.0+0.1$ & Treatment 14 & $4.0+0.1$ \\
\hline Treatment 7 & $2.0+0.5$ & Treatment 15 & $4.0+0.5$ \\
\hline Treatment 8 & $2.0+1.0$ & Treatment 16 & $4.0+1.0$ \\
\hline
\end{tabular}

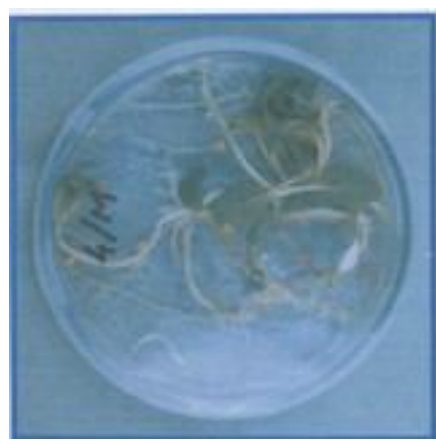

Fig. 1. Seed germination from eggplant cv. Jhumki on MS media without hormones at 7 days.

\subsection{Data collection}

\subsubsection{Days to callus initiation}

Generally, callus initiation started eight days of inoculation of explants. The number of callus initiated over a number of days was recorded.

\subsubsection{Per cent callus induction}

Percent callus induction was calculated on the basis of the number of explant placed and the number of callus induced.

\subsubsection{Color of callus}

Percentage callus induction $=\frac{\text { Number of explants induced calli }}{\text { Number of explants inoculated }} \times 100$
Fig. 2. Callus induction from eggplant cv. Jhumki on MS media with hormones (BAP and NAA).

After three weeks of inoculation, the color of the callus was observed visually and were graded as 3 for green, 2 for creamy and 1 for yellow color.

\section{a) Nature of callus}

After three weeks of inoculation, nature of callus was recorded and graded as 3 for compact, 2 for friable and 1 for looses of its texture.

\section{b) Abundance of callus}

After three weeks of inoculation, abundance of callus was recorded and graded as 3 for plenty, 2 for moderate and 1 for poor. 


\section{b) Weight of callus}

After three weeks of inoculation, the weight of callus was measured in gram (g) with the help of an electrical balance.

\section{c) Days of shoot initiation}

Shoot initiation started after 25-30 days of inoculation of explants. The number of shoots proliferated over a number of days were recorded. The mean value of the data provided the days required for shoot initiation.

d) Number of callus with shoot (per cent of shoot or plant regeneration)

Number of callus with shoot was recorded and percentage of shoot regeneration was calculated as

$\%$ shoot regeneration $=\frac{\text { Number of calli with plantlet }}{\text { Number of inoculated calli }} \times 100$

\section{e) Number of shoot per callus}

Some calli produced only single shoot while some others produced multiple shoots. So, number of shoots per callus was recorded at twenty five days interval and the mean was calculated using the following formula:

$$
\bar{X}=\frac{\sum \mathrm{Xi}}{\mathrm{n}}
$$

Where,

$$
\begin{array}{ll}
\overline{\mathrm{X}} & =\text { mean of shoot/callus } \\
\sum_{\mathrm{Xi}} & =\text { Summation } \\
\mathrm{n} & =\text { Number of shoot/callus } \\
& =\text { Number of observation }
\end{array}
$$

\section{f) Total number of shoots per Petridish}

Number of shoots per Petri dish was recorded at twenty five days interval and mean was calculated using the following formula:

$$
\overline{\mathrm{X}}=\frac{\sum \mathrm{Xi}}{\mathrm{n}}
$$

Where,

$$
\begin{array}{ll}
\overline{\mathrm{X}} & =\text { mean of shoot/Petri dish } \\
\sum_{\mathrm{X}} & =\text { Summation } \\
\mathrm{n} & =\text { Number of shoot/Petri dish } \\
& =\text { Number of observation }
\end{array}
$$

\section{g) Number of shoot with root}

Average number of shoot with root was calculated using the following formula:

$$
\bar{X}=\frac{\sum X i}{n}
$$

Where,

$$
\begin{array}{ll}
\overline{\mathrm{X}} & =\text { mean of shoot with root } \\
\sum_{\mathrm{X}} & =\text { Summation } \\
\mathrm{n} & =\text { Number of shoot with root } \\
& =\text { Number of observation }
\end{array}
$$

\section{h) Number of regenerated plantlets}

The established plants were calculated based on the number of plantlets placed in the pot and number of plants finally established or survived.

$\%$ plant establishment $=\frac{\text { Number of established plantlets }}{\text { Total number of plantlets }} \times 100$

\section{i) Transplantation of in vitro grown plantlets to the soil}

The plantlets with well-developed root system were removed from culture vessels with care and without damaging the roots. The agar was removed from the roots by washing with running tap water. After washing, the plantlets were transferred to small earthen pots filled with 1:2:1 of sand, soil and cow dung mixture. The plantlets were kept in diffused sunlight covered with polythene bag to prevent desiccation. Adequate moisture was supplied for 10 days and gradual exposure to air and light was allowed. After 30 days, the plantlets became $30 \mathrm{~cm}$ long and the survival rate was $75 \%$ Fig. 5 . 


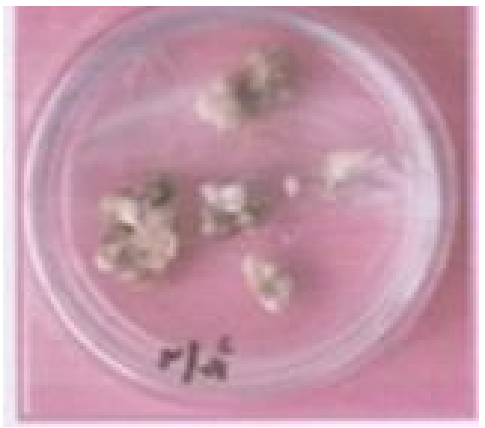

Fig. 3. Callus induction from eggplant cv. Jhumki on MS media with hormones (BAP and NAA).

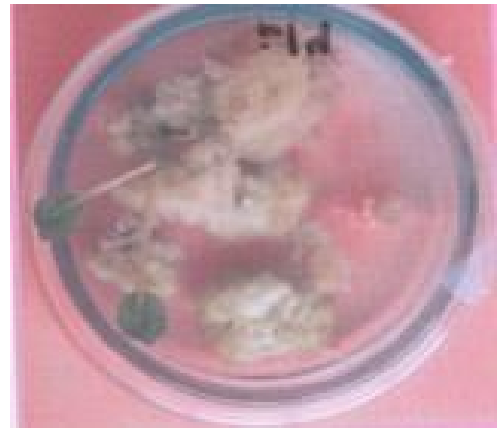

Fig. 4. Direct regeneration from eggplant cv. Jhumki on MS medium supplemented with $2.0 \mathrm{mg} / \mathrm{l} \mathrm{BAP}+0.5 \mathrm{mg} / 1 \mathrm{NAA}$.

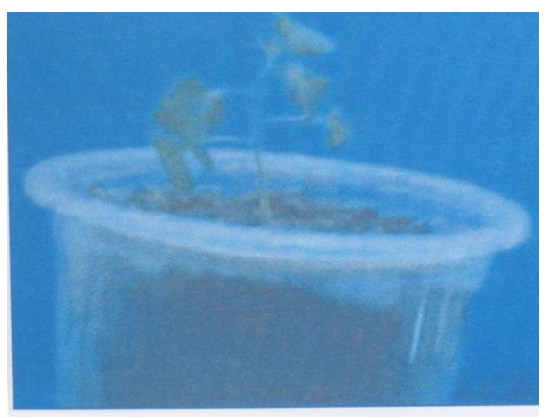

Fig. 5. plantlet of eggplant was transferred on earthen pot.

\subsection{Statistical analysis of data}

The data for the characters of the present study were statistically analyzed wherever applicable. The analysis of variance for different characters was performed and means were compared by the Duncan's Multiple Range Test (DMRT).

\section{Results and Discussion}

Plant regeneration from induced calli of eggplant in MS medium supplemented with different combinations of hormones was used. Among the explants used, stem was comparatively more responsive for callus induction than other explants such as leaf and root. The combined effect of explants and different combinations of BAP and NAA on callus induction are presented in Table 2. In case of stem, among the different combinations $2.0 \mathrm{mg} / \mathrm{l} \mathrm{BAP}+0.5 \mathrm{mg} / \mathrm{l} \mathrm{NAA}$ and $4.0 \mathrm{mg} / \mathrm{l} \mathrm{BAP}+0.5 \mathrm{mg} / \mathrm{l} \mathrm{NAA}$ showed better callus induction i.e. 14.600 and 11.600, respectively in Fig. 2. In case of leaf, the combination of $2.0 \mathrm{mg} / 1 \mathrm{BAP}+0.5 \mathrm{mg} / \mathrm{l} \mathrm{NAA}$ showed better callus induction i.e. 13.4 in Fig. 2. The explants cultured on MS medium without hormones did not produce any callus. It was also found that calli were induced in medium supplemented with BAP and NAA which is in agreement with that reported by Jayasree et al. (2001). The highest percentage of callus induction was found in MS media containing $2.0 \mathrm{mg} / \mathrm{l} \mathrm{BAP}+0.5 \mathrm{mg} / 1 \mathrm{NAA}$ from stem i.e. $48.666 \%$ followed by leaf in Fig. 3. 
Table 2. Combined effect of different combinations of BAP and NAA in MS medium on callus induction from stem, leaf and root explants of eggplant cv. Jhumki.

\begin{tabular}{|c|c|c|c|c|c|}
\hline \multicolumn{3}{|c|}{ Treatment combinations } & \multirow{3}{*}{$\begin{array}{l}\text { No. of explants showing } \\
\text { callus induction }\end{array}$} & \multirow{3}{*}{$\begin{array}{l}\text { Percent of callus } \\
\text { induction }\end{array}$} & \multirow{3}{*}{$\begin{array}{l}\text { Days required for callus } \\
\text { induction }\end{array}$} \\
\hline \multirow{2}{*}{ Explants } & \multicolumn{2}{|c|}{ Treatments } & & & \\
\hline & $\mathrm{BAP}(\mathrm{mg} / \mathrm{l})$ & NAA $(m g / l)$ & & & \\
\hline \multirow{16}{*}{ Stem } & \multirow{4}{*}{0} & 0 & $0.000 \mathrm{R}$ & $0.000 \mathrm{R}$ & $0.000 \mathrm{I}$ \\
\hline & & 0.1 & $7.000 \mathrm{JKLMN}$ & 23.333 JKLMN & 10.400 ABCDEF \\
\hline & & 0.5 & $6.600 \mathrm{KLMNO}$ & $22.000 \mathrm{KLMNO}$ & 10.44 ABCDEF \\
\hline & & 1.0 & 7.400 HIJKLM & 24.066 HIJKIM & $10.600 \mathrm{ABCDEF}$ \\
\hline & \multirow{4}{*}{2.0} & 0 & 6.200 LMNO & 20.660 LMNO & $10.400 \mathrm{ABCDEF}$ \\
\hline & & 0.1 & 8.600 FGHI & 28.666 FGHI & 9.600 EBCDEFG \\
\hline & & 0.5 & $14.600 \mathrm{~A}$ & $48.666 \mathrm{~A}$ & $8.200 \mathrm{GH}$ \\
\hline & & 1.0 & 9.600 DEFG & 32.000 DEFG & 9.600 EFG \\
\hline & \multirow{4}{*}{3.0} & 0 & $6.800 \mathrm{KLMNO}$ & $22.660 \mathrm{KLMNO}$ & $11.200 \mathrm{ABCDE}$ \\
\hline & & 0.1 & 9.400 DEFG & 31.330 DEFG & $10.800 \mathrm{ABCDE}$ \\
\hline & & 0.5 & $10.200 \mathrm{DE}$ & $34.000 \mathrm{DE}$ & 9.800 DEFG \\
\hline & & 1.0 & 9.200 DEFG & 30.666 DEFG & 10.600 ABCDEF \\
\hline & \multirow{4}{*}{4.0} & 0 & $6.600 \mathrm{KLMNO}$ & $22.000 \mathrm{KLMNO}$ & $11.400 \mathrm{ABCDE}$ \\
\hline & & 0.1 & $10.000 \mathrm{DEF}$ & 33.333 DEF & $11.200 \mathrm{ABCDE}$ \\
\hline & & 0.5 & $11.600 \mathrm{C}$ & $38.666 \mathrm{C}$ & $10.000 \mathrm{CDEF} \backslash \mathrm{G}$ \\
\hline & & 1.0 & $10.000 \mathrm{DEF}$ & 33.333 DEF & $11.400 \mathrm{ABCDE}$ \\
\hline \multirow{16}{*}{ Leaf } & \multirow{4}{*}{0} & 0 & $0.000 \mathrm{R}$ & $0.000 \mathrm{R}$ & $0.000 \mathrm{ABCDE}$ \\
\hline & & 0.1 & $5.800 \mathrm{NOP}$ & $19.333 \mathrm{NOP}$ & $11.000 \mathrm{ABCDE}$ \\
\hline & & 0.5 & $6.000 \mathrm{MNO}$ & $20.000 \mathrm{MNO}$ & $10.800 \mathrm{ABCDE}$ \\
\hline & & 1.0 & 9.200 DEFG & $30.666 \mathrm{DEFG}$ & $10.600 \mathrm{ABCDF}$ \\
\hline & \multirow{4}{*}{2.0} & 0 & 4.600 PQ & 15.330 PQ & $11.000 \mathrm{ABCDE}$ \\
\hline & & 0.1 & 7.400 IJKLM & 24.660 IJKLM & 10.200 BCDEF \\
\hline & & 0.5 & $13.400 \mathrm{~B}$ & $44.660 \mathrm{~B}$ & $8.600 \mathrm{FH}$ \\
\hline & & 1.0 & $9.800 \mathrm{DEF}$ & $32.666 \mathrm{DEF}$ & $10.800 \mathrm{ABCDE}$ \\
\hline & \multirow{4}{*}{3.0} & 0 & $4.400 \mathrm{Q}$ & $14.666 \mathrm{Q}$ & $10.800 \mathrm{ABCDE}$ \\
\hline & & 0.1 & 6.400 KLMNO & 21.333 KLMNO & $10.800 \mathrm{ABCDE}$ \\
\hline & & 0.5 & $6.200 \mathrm{LMNO}$ & 20.660 LMNO & 11.200 ABCDE \\
\hline & & 1.0 & $10.000 \mathrm{DEF}$ & 33.333 DEF & $10.800 \mathrm{ABCDE}$ \\
\hline & \multirow{4}{*}{4.0} & 0 & $4.400 \mathrm{Q}$ & $14.666 \mathrm{Q}$ & 11.400 ABCDE \\
\hline & & 0.1 & $7.600 \mathrm{HIJK}$ & 25.333 HIJK & $11.600 \mathrm{ABCDE}$ \\
\hline & & 0.5 & 7.400 IJKLM & 24.661 IJKLM & $11.600 \mathrm{ABCDE}$ \\
\hline & & 1.0 & $8.600 \mathrm{FGHI}$ & 28.660 FGHI & 11.200 ABCDE \\
\hline
\end{tabular}




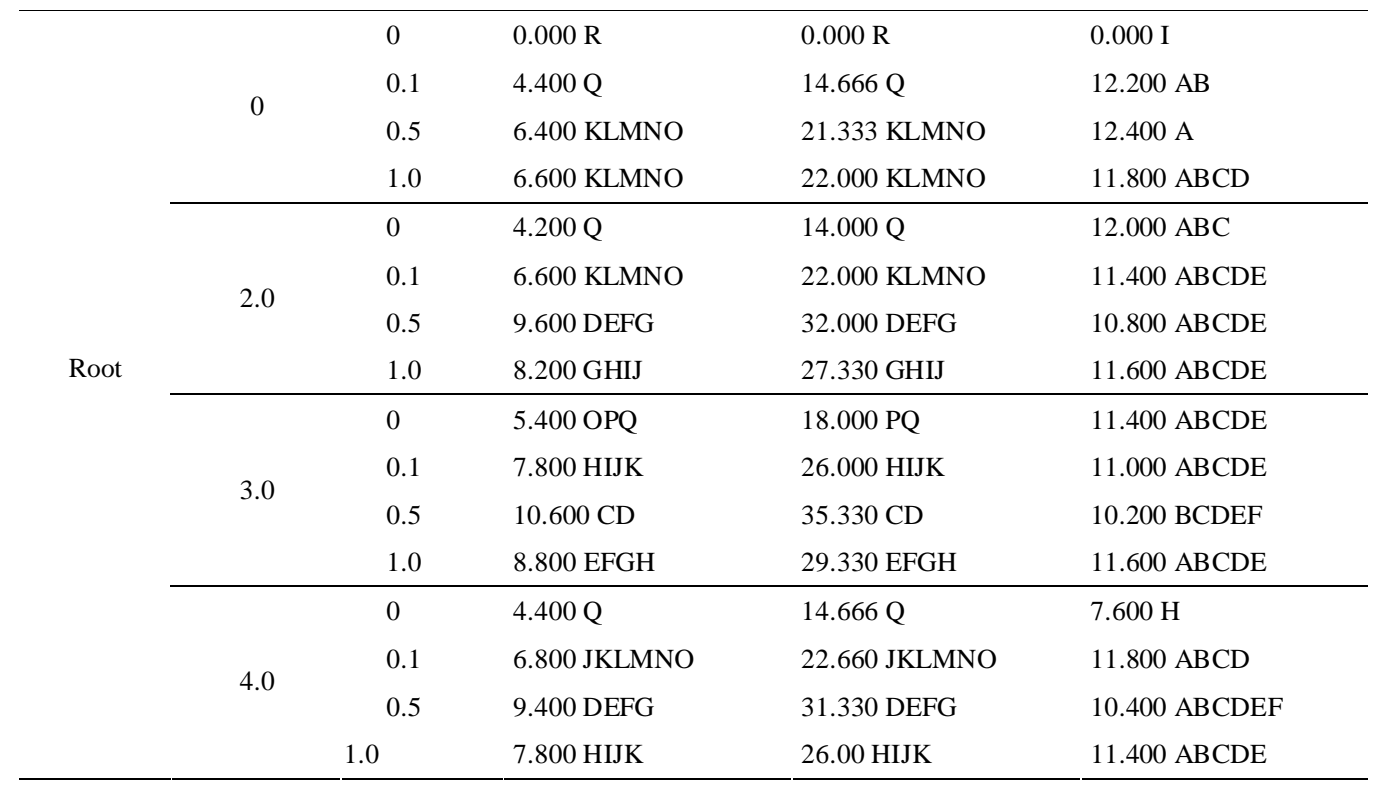

The combination of $2.0 \mathrm{mg} / \mathrm{l} \mathrm{BAP}+0.5 \mathrm{mg} / \mathrm{l}$ NAA from stem days required for callus induction was 8.2 days. While it required 8.6 days for callus induction from leaf explants with $2.0 \mathrm{mg} / \mathrm{l}$ BAP $+0.1 \mathrm{mg} / \mathrm{l}$ NAA. So, callus induction from stem required minimum days.

Stem and leaf segments were used as explants to observe their callus weight. The highest fresh weight of callus was obtained from stem i.e. 0.321 $\mathrm{g}$ and callus weight of leaf was $0.291 \mathrm{~g}$. Different concentrations of BAP and NAA influenced the average fresh weight of callus. The highest callus weight obtained from MS medium supplemented with $2.0 \mathrm{mg} / 1 \mathrm{BAP}$ was $0.407 \mathrm{~g}$ and $0.5 \mathrm{mg} / \mathrm{l}$ NAA was $0.417 \mathrm{~g}$. On the contrary, explants cultured on MS media containing without hormones did not produce any callus. Among the different combination of $2.0 \mathrm{mg} / \mathrm{l} \mathrm{BAP}+0.5$ mg/l NAA showed highest callus weight from the stem i.e. $1.12 \mathrm{~g}$. In case of leaf, $2.0 \mathrm{mg} / \mathrm{l} \mathrm{BAP}$ $+0.5 \mathrm{mg} / \mathrm{l}$ NAA showed highest callus weight from the leaf i.e. $0.500 \mathrm{~g}$.
The combined effect of different combinations of BAP and NAA in MS medium on plant regeneration from stem, leaf and root of eggplant cv. Jhumki are presented in Table 3. Various combinations of supplements showed significant variation in regeneration ability. Among the combinations, $2.0 \mathrm{mg} / \mathrm{l} \mathrm{BAP}+0.5 \mathrm{mg} / \mathrm{l} \mathrm{NAA}$ showed the highest regeneration of plantlets from stem (3.400). The regeneration of plantlets was (1.6) from leaf in $2.0 \mathrm{mg} / \mathrm{l} \mathrm{BAP}$ and $0.5 \mathrm{mg} / \mathrm{l}$ NAA combinations. Root showed the lowest regeneration. The percentage of regeneration was recorded the highest in MS media containing 2.0 $\mathrm{mg} / \mathrm{l} \mathrm{BAP}+0.5 \mathrm{mg} / \mathrm{l} \mathrm{NAA}$ from stem. i.e. $23.28 \%$ and days required for regeneration is minimum (38.8 days) in Fig. 4. The percentage of regeneration was the highest in $2.0 \mathrm{mg} / \mathrm{l} \mathrm{BAP}$ $+0.5 \mathrm{mg} / 1 \mathrm{NAA}$ from leaf. i.e. $1.6(11.94 \%)$ and percentage of regeneration from root was the lowest. Plant regeneration from leaf in $2.0 \mathrm{mg} / 1$ $\mathrm{BAP}+0.5 \mathrm{mg} / \mathrm{l} \mathrm{NAA}$ combination required minimum days (46.2 days). So, we found that 2.0 $\mathrm{mg} / \mathrm{l} \mathrm{BAP}+0.5 \mathrm{mg} / \mathrm{l}$ NAA combination in stem is the best for regeneration in eggplant. 
Table 3. Combined effect of different combinations with BAP and NAA in MS medium on plant regeneration from stem, leaf and root of eggplant cv. Jhumki

\begin{tabular}{|c|c|c|c|c|c|}
\hline \multicolumn{3}{|c|}{ Treatment combinations } & \multirow{2}{*}{$\begin{array}{l}\text { No. of plants } \\
\text { regenerated } \\
\text { through callus }\end{array}$} & \multirow{2}{*}{$\begin{array}{l}\text { Percent of } \\
\text { regeneration }\end{array}$} & \multirow{2}{*}{$\begin{array}{l}\text { Days required } \\
\text { for regeneration }\end{array}$} \\
\hline Explants & $\begin{array}{c}\mathrm{BAP} \\
(\mathrm{mg} / \mathrm{l})\end{array}$ & $\begin{array}{l}\text { NAA } \\
(\mathrm{mg} / \mathrm{l})\end{array}$ & & & \\
\hline \multirow{16}{*}{ Stem } & \multirow{4}{*}{0} & 0 & - & - & - \\
\hline & & 0.1 & - & - & - \\
\hline & & 0.5 & - & - & - \\
\hline & & 1.0 & - & - & - \\
\hline & \multirow{4}{*}{2.0} & 0 & $0.200 \mathrm{CD}$ & $3.222 \mathrm{CD}$ & $39.200 \mathrm{G}$ \\
\hline & & 0.1 & $0.600 \mathrm{CD}$ & $6.976 \mathrm{CD}$ & $39.800 \mathrm{G}$ \\
\hline & & 0.5 & $3.400 \mathrm{~A}$ & $23.287 \mathrm{~A}$ & $38.800 \mathrm{G}$ \\
\hline & & 1.0 & $0.600 \mathrm{CD}$ & $6.25 \mathrm{CD}$ & $39.000 \mathrm{G}$ \\
\hline & \multirow{4}{*}{3.0} & 0 & $0.200 \mathrm{CD}$ & $2.94 \mathrm{CD}$ & $39.400 \mathrm{G}$ \\
\hline & & 0.1 & $0.800 \mathrm{C}$ & $8.510 \mathrm{C}$ & $39.800 \mathrm{G}$ \\
\hline & & 0.5 & $0.800 \mathrm{C}$ & $7.843 \mathrm{C}$ & $39.800 \mathrm{G}$ \\
\hline & & 1.0 & $0.600 \mathrm{CD}$ & $6.521 \mathrm{CD}$ & $39.600 \mathrm{G}$ \\
\hline & \multirow{4}{*}{4.0} & 0 & $0.400 \mathrm{CD}$ & $6.060 \mathrm{CD}$ & $40.000 \mathrm{G}$ \\
\hline & & 0.1 & $0.600 \mathrm{CD}$ & $6.000 \mathrm{CD}$ & $40.000 \mathrm{G}$ \\
\hline & & 0.5 & $0.400 \mathrm{CD}$ & $3.448 \mathrm{CD}$ & $39.800 \mathrm{G}$ \\
\hline & & 1.0 & $0.400 \mathrm{CD}$ & $4.00 \mathrm{CD}$ & $39.600 \mathrm{G}$ \\
\hline \multirow[t]{13}{*}{ Leaf } & \multirow{4}{*}{0} & 0 & - & - & - \\
\hline & & 0.1 & - & - & - \\
\hline & & 0.5 & - & - & - \\
\hline & & 1.0 & - & - & - \\
\hline & \multirow{4}{*}{2.0} & 0 & $0.400 \mathrm{CD}$ & $8.695 \mathrm{CD}$ & $48.800 \mathrm{CD}$ \\
\hline & & 0.1 & $0.600 \mathrm{CD}$ & $8.108 \mathrm{CD}$ & $48.000 \mathrm{DE}$ \\
\hline & & 0.5 & $1.600 \mathrm{~B}$ & $11.940 \mathrm{~B}$ & $46.200 \mathrm{~F}$ \\
\hline & & 1.0 & $0.600 \mathrm{CD}$ & $6.122 \mathrm{CD}$ & $49.000 \mathrm{CD}$ \\
\hline & \multirow{4}{*}{3.0} & 0 & $0.400 \mathrm{CD}$ & $9.090 \mathrm{CD}$ & $48.800 \mathrm{CD}$ \\
\hline & & 0.1 & $0.400 \mathrm{CD}$ & $6.25 \mathrm{CD}$ & $48.400 \mathrm{CDE}$ \\
\hline & & 0.5 & $0.600 \mathrm{CD}$ & $9.677 \mathrm{CD}$ & $47.400 \mathrm{E}$ \\
\hline & & 1.0 & $0.400 \mathrm{CD}$ & $4.00 \mathrm{CD}$ & 48.200CDE \\
\hline & 4.0 & 0 & $0.200 \mathrm{CD}$ & $4.545 \mathrm{CD}$ & $49.000 \mathrm{CD}$ \\
\hline
\end{tabular}




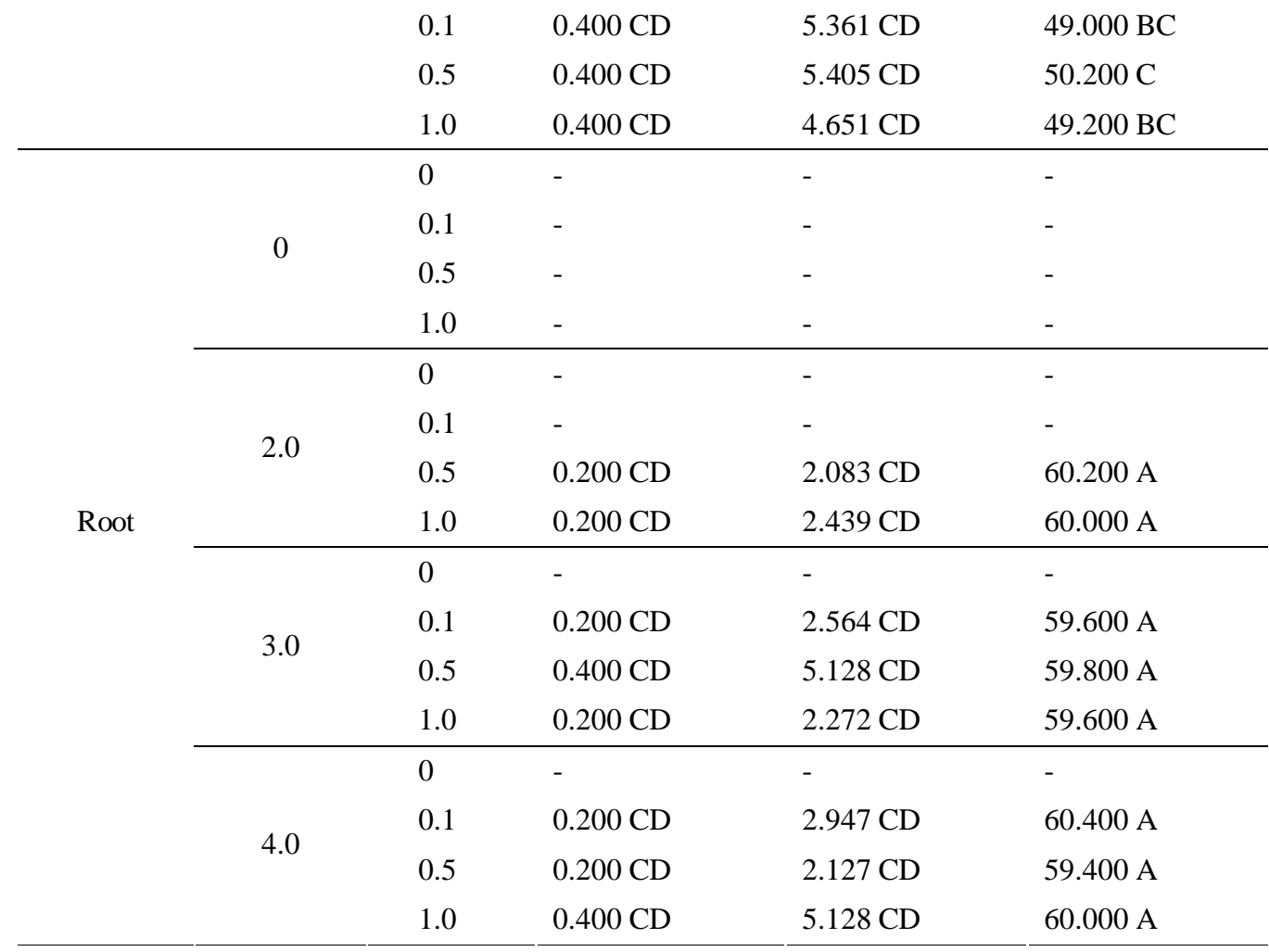

\section{Conclusions}

Explants were cultured on MS media supplemented with different combinations and concentrations of BAP $(0,2.0,3.0$ and $4.0 \mathrm{mg} / \mathrm{l})$ and NAA $(0,0.1,0.5$, and $1.0 \mathrm{mg} / \mathrm{l})$. The highest amount of callus $(48.66 \%)$ was produced on MS medium containing $2.0 \mathrm{mg} / \mathrm{l} \mathrm{BAP}$ and $0.5 \mathrm{mg} / \mathrm{l}$ NAA from stem after 8.2 days. The growth of callus was faster on MS media supplemented with $2.0 \mathrm{mg} / \mathrm{l} \mathrm{BAP}$ and $0.5 \mathrm{mg} / \mathrm{l} \mathrm{NAA}$ from the stem. The highest fresh weight of callus was $1.120 \mathrm{~g}$ from the stem explants and $0.5 \mathrm{~g}$ from the leaf. The maximum number of plant regeneration through callus from stem containing $2.0 \mathrm{mg} / \mathrm{l}$ BAP and $0.5 \mathrm{mg} / \mathrm{l}$ NAA were 3.4 (23.287\%) and from leaf containing $2.0 \mathrm{mg} / \mathrm{l} \mathrm{BAP}$ and $0.5 \mathrm{mg} / \mathrm{l}$ NAA were $1.6(11.94 \%)$. The best number of shoot regenerated through callus from stem containing $2.0 \mathrm{mg} / \mathrm{l} \mathrm{BAP}$ and $0.5 \mathrm{mg} / \mathrm{l} \mathrm{NAA}$ was $3.4(23.287 \%)$ and days required for 38.8 days.

\section{References}

Anwar, S; Sabana, D.; Siddiqui, S. A.; Shahzad, A. and Din, S. 2002. Clonal Propagation of brinjal, Solanum melongena, through young petiolated leaf culture. Bionotesx, 4(3): 61 .

Cardenas, A. M.; Verde- star; Villarneal, J.; Valader, C.M.C.and Meiti, R. K.1997. In vitro tissue culture of wild chilli "Chile piquin" (Capsicum annuum L.) var. Aviculre, D. Arcy and and Esbaugh: an alternative method for propagation. Phyton., 60(1/2): 99-102 [Cited from Horticultural Abstracts, 67(12): 1345, 1997]. 
Hitomi, A.; Amogai, H. and Ezura, H.1998. The influence of auxin type of the array of somaclonal variants generated from somatic embryogenesis of eggplant (Solanum melongena L.) Plant Breeding. 117(4): 379-383.

Jahan, M. A. A. and Hadiuzzaman, S. 1996. Callus induction and plant regeneration from different explants of Solanum nigrum L. seedlings. Plant Tissue Culture and Biotechnology.6 (1): 57-62.

Jayasree, T.; Paban ,V.; Ramesh ,M.; Rao ,A.V. and Reddy, K. J.M. 2001. Somatic embryogenesis from leaf cultures of potato. Plant Cell Tissue Organ Culture, 64(1): 13-17.

Larkin, P.J. and Scowcroft, W.R. 1981. Somaclonal variation- a novel source of variability from cell cultures for plant environment. Theory of Applied Genetics, 60: 197-214.

Mohamed, M. F. 2003. Enabling ex situ conservation of landrace field collections from mature pepper plants via bud culture. Capsicum and Eggplant Newsletter, 22: 99-102.

Murashige, T. and Skoog, F. 1962. A revised medium for rapid growth and Bioassays with Tobacco tissue cultures. Plant Physiology, Lancaster, 15: 473-497.

Ofori, A., Heiko, C. and Becker. 2008. Breeding of Brassica rapa for biogas production: Heterosis and combining ability of biomass yield. Bioenergetic Research. 1:98-104.

Shukla GS and Upadhyay VB (2000) Economic Zoology (4th edt.). Rastogi Publication, Gangotri Shivaji road, India. 121-123 pp. 